\title{
SPLIT PETALS IN CRUCIFERS
}

\section{T. P. PALMER}

Crop Research Division, Department of Scientific and Industrial Research, Christchurch, New Zealand

\section{INTRODUCTION}

Flowers of most Crucifers have four entire petals, six stamens and a two-valved ovary. In members of the genera, Matthiola, Raphanus and Brassica lines or plants have been found in which some flowers deviate from this formula. In B. napus (swede), B. oleracea and $R$. sativa (radish) some of the petals were divided near their base, and lines in which this was fairly common were isolated. This division probably resulted from an early splitting of the petal primordia. Plants with the same abnormality have been seen in M. bicornis.

TABLE I

Number of normal and abnormal flowers at different times

\begin{tabular}{|c|c|c|c|c|c|c|c|c|c|c|c|c|}
\hline \multirow{3}{*}{$\begin{array}{l}\text { Plant } \\
-- \\
9052 / 1\end{array}$} & \multirow{2}{*}{$\frac{10 / 10 / 55}{\text { N. A. }}$} & \multirow{2}{*}{$\frac{13 / 10 / 55}{\text { N. A. }}$} & \multicolumn{2}{|c|}{$17 / 10 / 55$} & \multicolumn{2}{|c|}{$20 / 10 / 55$} & \multicolumn{2}{|c|}{$25 / 10 / 55$} & \multicolumn{2}{|c|}{$28 / 10 / 55$} & \multicolumn{2}{|c|}{ I $/ 11 / 55$} \\
\hline & & & N. & A. & N. & A. & N. & A. & & A. & N. & \\
\hline & 15 & 304 & 57 & 5 & 70 & 2 & $4^{8}$ & 20 & 80 & $4^{8}$ & 70 & 60 \\
\hline $905^{2} / 4$ & 5 & 252 & 46 & 2 & 70 & & 100 & 7 & 120 & 12 & 150 & 20 \\
\hline $9053 / 2$ & 8 & $3^{2}$ & 71 & 1 & $9^{\circ}$ & 9 & 70 & 44 & 80 & 60 & 120 & 30 \\
\hline $9054 / 2$ & I & 18 & 33 & & 64 & & 76 & 2 & 100 & 6 & 120 & 17 \\
\hline $9054 / 4$ & 12 & 33 & 58 & I & 60 & & 100 & 2 & 110 & 16 & I 50 & 5 \\
\hline $9054 / 5$ & 18 & $4^{2}$ & 66 & I & 50 & 7 & 99 & $2 \mathrm{I}$ & 100 & 53 & 160 & 20 \\
\hline
\end{tabular}

In the radish population which produced divided petals, some stamens were reduced or absent, or fused with petals or the pistil, and some petals reduced or absent.

In $B$. napus, $B$. oleracea and $M$. bicornis usually only one petal on a flower was affected, though as many as three have been noted. In affected radish flowers, divided petals were often more numerous.

It is not known whether the stamen irregularities in the radish were causally connected with the petal abnormality, or whether a separate agent was responsible for their appearance. The frequency of affected flowers on different swede plants has varied from $\frac{1}{2000}$ to $\frac{1}{2}$. In both the swede and radish, divided petals were not distributed on the plants in any clear consistent pattern. However, their appearance has not been at random, as their frequency varied during the flowering season (see table $\mathrm{I}$ ).

On the swede, numerous branches flower at the same time, but there was no conclusive evidence that the proportion of affected flowers varied from branch to branch at any one time. Of 64 betweenbranch comparisons tested in 1953, $\chi^{2}$ was significant at the 5 per cent. level in three cases, and at the I per cent. level in two. 
In the radish, affected flowers on plants with a large number of abnormal flowers had more divided petals than on plants with a smaller proportion of affected flowers.

Some results on the inheritance of this character are reported here.

\section{MATERIAL}

The inheritance of this abnormality has been studied in the following populations.

1. Families of Calder swede.

2. Families of a radish population known locally as Chinese turnip.

Divided petals were common on many plants in both these populations.

3. $F_{1}$ 's between Calder and some unrelated normal swedes.

4. $F_{1}, F_{2}, F_{3}$, parental and back-cross generations of hybrids between an abnormal

Calder swede plant and a normal Grandmaster plant. No divided petals

have been seen on some 15,00o Grandmaster flowers.

Lot 1 was grown in 1951, 1953 and 1954 ; lot 2 in 1951 and $1953 ;$ lot 3 in 1955 ; and lot 4 in 1954,1955 and 1956.

In 1951 and 1953, seeds were sown in their permanent positions in the open. In 1954 seeds were sown in the autumn and transferred to the glasshouse in the spring. In 1955 some were planted in the glasshouse and some in the field. The glasshouse consisted of several cells, and each plant was assigned to a cell at random.

Flowers were classified every three or four days. With this interval, no flower was scored twice but few were missed.

Throughout, $\mathrm{N}$ stands for a normal flower, or for a plant with no abnormal flowers, A for an abnormal flower or for a plant with any abnormal flowers.

\section{VARIATION WITHIN CALDER SWEDE AND RADISH}

\section{(i) Presence of abnormal flowers}

Swede 1953. The families grown were derived from open pollinated Calder plants by two generations of selfing, or were $\mathrm{F}_{2}$ 's of crosses between open pollinated Calder plants. Plants with any abnormal flowers were classified as abnormal. Results are shown in table 2.

Apart from the aberrant $F_{2}$ family in the cross of $6 / 10 \times 6 / 9$, these results could be explained by assuming that one dominant gene in this population caused the occurrence of abnormal plants.

Swede 1954. Thirteen plants were progeny tested in 1954. Eleven of these were from segregating families, and two were from normal plants. Results are shown in table 3.

The two normal plants tested failed to breed true, and in their progeny only one normal occurred in a total of twelve. Among the progenies of the abnormal plants from mixed families, of which onethird would be expected to be true breeding abnormals, and twothirds to segregate $1: 3$, only one contained any normal plants, and it only one in a total of 22. Clearly, any idea of a single dominant gene as a cause of the presence of abnormal flowers on plants in the Calder population is not tenable.

Radish 1953. In 1951 four plants were inter-crossed and selfed. Plants 1 and 4 were classified as normal, 2 and 3 as abnormal, but 
only a few flowers on each plant were examined. Results from these matings are given in table 4 .

TABLE 2

Abnormal plants in Calder families 1953

\begin{tabular}{|c|c|c|c|c|}
\hline \multicolumn{2}{|c|}{ Parent } & \multicolumn{3}{|c|}{ Progeny } \\
\hline \multirow{2}{*}{ Plant no. } & Flowers & \multirow{2}{*}{ Generation } & \multicolumn{2}{|c|}{ Plants } \\
\hline & N. A. & & N. & \\
\hline \multirow{5}{*}{$\begin{array}{l}6 / 10 \\
6 / 12 \\
6 / 3 \\
6 / 5\end{array}$} & \multirow{5}{*}{$\begin{array}{rr}19 & \text { I } \\
\text { I } & \text { 18 } \\
16 & 0 \\
8 & 4\end{array}$} & \multirow{5}{*}{$\begin{array}{l}\mathrm{S}_{2} \\
\mathrm{~S}_{2} \\
\mathrm{~S}_{2} \\
\mathrm{~S}_{2}\end{array}$} & & \\
\hline & & & & 12 \\
\hline & & & 3 & 0 \\
\hline & & & 0 & 7 \\
\hline & & & & 26 \\
\hline \multirow[t]{3}{*}{$6 / 1 \times 6 / 12$} & \multirow[t]{3}{*}{$6: 4 \times 1: 18$} & \multirow[t]{3}{*}{$F_{2}$} & 0 & 3 \\
\hline & & & $\begin{array}{l}0 \\
I\end{array}$ & $\begin{array}{l}2 \\
3\end{array}$ \\
\hline & & & & \\
\hline \multirow[t]{4}{*}{$6 / 3 \times 6 / 1$} & \multirow[t]{4}{*}{$16: 0 \times 6: 4$} & \multirow[t]{4}{*}{$F_{2}$} & 3 & \\
\hline & & & & $\begin{array}{l}4 \\
9\end{array}$ \\
\hline & & & 4 & Io \\
\hline & & & 9 & 26 \\
\hline \multirow[t]{3}{*}{$6 / 10 \times 6 / 9$} & \multirow[t]{4}{*}{$19: 1 \times 5: 2$} & \multirow[t]{4}{*}{$\mathbf{F}_{2}$} & I & II \\
\hline & & & & \\
\hline & & & 8 & I3 \\
\hline All plants & & & 27 & 73 \\
\hline
\end{tabular}

TABLE 3

Affected plants in Calder families 1954

\begin{tabular}{|c|c|c|c|c|c|c|}
\hline Parent plant & \multicolumn{2}{|c|}{$\begin{array}{l}\text { Abnormal from } \\
\text { abnormal family }\end{array}$} & \multicolumn{2}{|c|}{$\begin{array}{l}\text { Abnormal from } \\
\text { mixed family }\end{array}$} & \multicolumn{2}{|c|}{$\begin{array}{l}\text { Normal from } \\
\text { mixed family }\end{array}$} \\
\hline Progeny & $\begin{array}{c}\mathrm{N} \\
\mathrm{o} \\
\mathrm{I} \\
\mathrm{o}\end{array}$ & $\begin{array}{r}\text { A. } \\
5 \\
6 \\
3\end{array}$ & $\begin{array}{c}\mathrm{N} . \\
\mathrm{O} \\
\mathrm{O} \\
\mathrm{O} \\
\mathrm{O} \\
\mathrm{O} \\
\mathrm{I} \\
\mathrm{O} \\
\mathrm{O}\end{array}$ & $\begin{array}{r}\text { A. } \\
6 \\
10 \\
2 \\
6 \\
2 \\
2 \mathrm{I} \\
2 \mathrm{I} \\
8\end{array}$ & $\begin{array}{c}\text { N. } \\
\text { I } \\
0\end{array}$ & $\begin{array}{r}\text { A. } \\
6 \\
5\end{array}$ \\
\hline Total & I & I4 & I & 76 & I & I I \\
\hline
\end{tabular}

Some abnormals occurred in the $\mathrm{N} \times \mathrm{N}$ matings, and one normal in the $\mathrm{A} \times \mathrm{A}$ matings. A single gene is not sufficient to account for these results. The $\mathrm{A} \times \mathrm{A}$ matings left more abnormals than the $\mathrm{N} \times \mathrm{A}$ combinations, which in turn gave a higher frequency than the $\mathrm{N} \times \mathrm{N}$. 


\section{(ii) Expression of abnormality}

The proportion of abnormal flowers on affected plants varied from plant to plant and from time to time on any one plant. This variation from time to time poses a sampling problem which was not satisfactorily resolved. The percentage of abnormal flowers per plant was computed, and its distribution among plants of these populations was found to be strongly skewed. The distribution of log of the percentage, or of the values obtained by the arc sine transformation, failed to remove

TABLE 4

Abnormal plants in Radish families

\begin{tabular}{|c|c|c|c|}
\hline \multicolumn{2}{|c|}{ Parent } & \multicolumn{2}{|c|}{ Progeny } \\
\hline Type & Plant no. & N. & A. \\
\hline \multirow[t]{2}{*}{$\mathrm{N} \times \mathrm{N}$} & 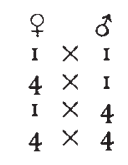 & $\begin{array}{r}4 \\
29 \\
3 \\
3\end{array}$ & $\begin{array}{l}0 \\
2 \\
1 \\
3\end{array}$ \\
\hline & & 39 & 6 \\
\hline $\mathrm{N} \times \mathrm{A}$ & $\begin{array}{lll}2 & \times & 1 \\
3 & \times & 1 \\
4 & \times & 2 \\
2 & \times & 4 \\
3 & \times & 4\end{array}$ & $\begin{array}{l}2 \\
5 \\
6 \\
7 \\
4\end{array}$ & $\begin{array}{r}5 \\
24 \\
9 \\
8 \\
2\end{array}$ \\
\hline \multirow[t]{2}{*}{$\mathrm{A} \times \mathrm{A}$} & $\begin{array}{l}2 \times 2 \\
3 \times 2 \\
2 \times 3\end{array}$ & $\begin{array}{r}24 \\
I \\
0 \\
0\end{array}$ & $\begin{array}{l}4^{8} \\
10 \\
19 \\
15\end{array}$ \\
\hline & & I & 44 \\
\hline
\end{tabular}

all this skewness. The second of these transformations has been used in computing means and variances.

Plants with no abnormal flowers also pose a problem. In some cases it is reasonable to assume that the incidence in these plants is low and that they would have produced abnormal flowers had they produced enough flowers. But it is also possible that they represent a different sort of plant which does not produce abnormals. When family means have been computed, all normal plants have been omitted. In fact, there was a correlation between the proportion of affected plants in a family and the percentage of abnormal flowers on a plant, so that when family means are compared, the omission of normal plants tends to reduce family differences.

Swede 1953. Progeny means of affected plants for progenies with five or more abnormal plants are shown in table 5. Differences 
between families were significant. If family 3449 was omitted, however, the remaining family means were not significantly different.

TABLE 5

Swede family means 1953

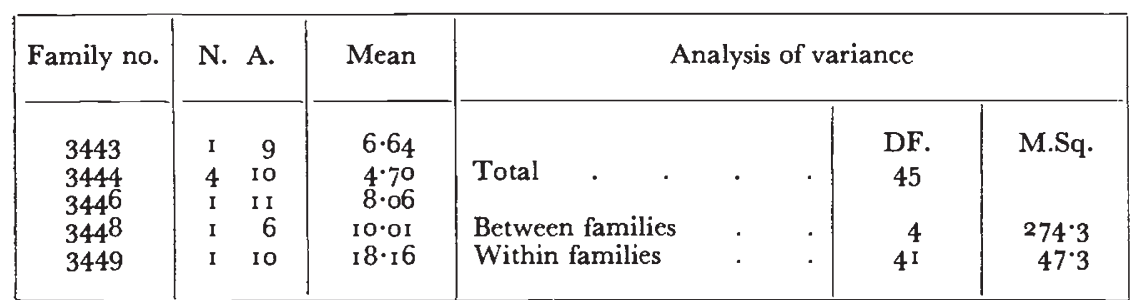

TABLE 6

Swede family means, 1954

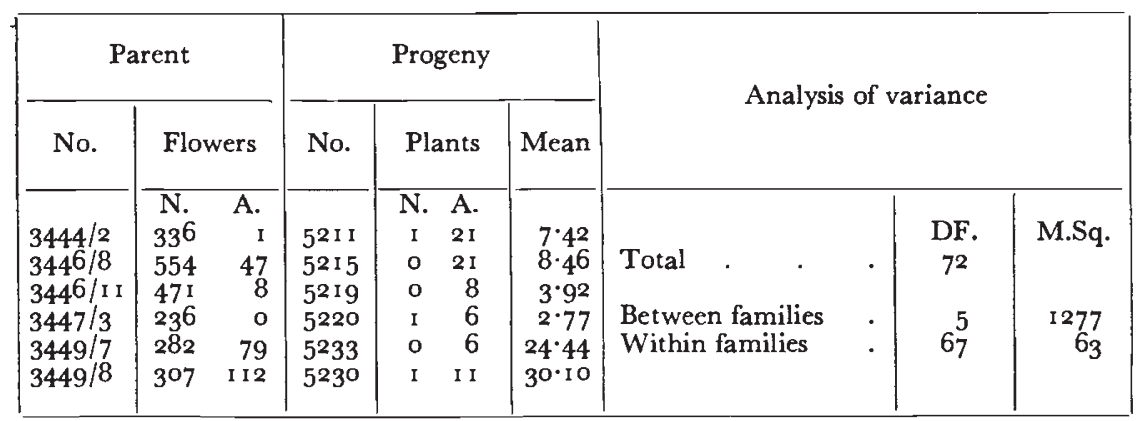

TABLE 7

Mean abnormal flowers per plant in Radish families, 1953

\begin{tabular}{|c|c|c|c|c|}
\hline \multicolumn{2}{|c|}{ Parents } & \multicolumn{3}{|c|}{ Progeny } \\
\hline Plants & Type & Mean & N. & A. \\
\hline $2 \times 2$ & $\mathbf{A} \times \mathbf{A}$ & $26 \cdot 3$ & I & 10 \\
\hline $2 \times 3$ & $\mathbf{A} \times \mathbf{A}$ & $31 \cdot 6$ & 0 & 15 \\
\hline $3 \times 2$ & $\mathrm{~A} \times \mathrm{A}$ & 33.3 & 0 & 19 \\
\hline $3 \times 1$ & $A \times N$ & $30 \cdot 1$ & 5 & 24 \\
\hline$I \times 2$ & $\mathrm{~N} \times \mathbf{A}$ & 8.6 & 2 & 5 \\
\hline $2 \times 4$ & $\mathrm{~A} \times \mathrm{N}$ & II. 3 & 7 & 8 \\
\hline $4 \times 2$ & $\mathbf{N} \times \mathbf{A}$ & 13.3 & 6 & 9 \\
\hline
\end{tabular}

Swede 1954. The relevant data are shown in table 6.

Progeny means were again different. When families 5230 and 5233 were omitted, there were significant differences between the other families. The family with the highest mean in 1953 (3449) left two progenies with the highest means in I954.

The mean number of flowers classified on each plant was about the same in both years (557 and 547).

Radish 1953. Results are shown in table 7. 
The families fell into two groups, significantly different from each other, but with no significant differences within each group. The progenies with a high mean had a higher proportion of abnormal plants than those with a low mean.

In the radish, affected flowers often had more than one divided petal. As many as five extra lobes have been recorded, and many flowers had two or three. The mean number of extra petal lobes per abnormal flower was closely correlated with the percentage of abnormal flowers per plant $(r=+0 \cdot 86)$.

\section{(iii) Discussion}

In both the swede and radish the proportion of abnormal flowers varied from plant to plant and from time to time. In both, differences between family means occurred, and in neither population could the presence of abnormal flowers be explained by the action of one gene. These similarities suggest that genetic control of this character is similar in the two populations. Perhaps the most plausible explanation of these results is that all, or most, plants in these populations are potentially capable of producing abnormal flowers, but that some are more likely to do so than others, this probability being genetically and environmentally modified. In support of this interpretation, several plants with normal phenotypes have produced abnormal progenies, and none which have been well tested have failed to do so. Evidence of genetic modification is provided by the famly differences in mean expression on abnormal plants, and parent-offspring correlations in mean expression, and by the different frequencies of abnormal plants in different families. Differences on the same plant during the flowering season suggest that environmental variations affect character expression.

We shall see in the next section that the potentiality to produce abnormal flowers is not only genetically modified, but also genetically determined.

\section{VARIATION IN CROSSES BETWEEN CALDER AND GRANDMASTER SWEDES}

\section{(i) Material}

Divided petals have been observed in only two varieties of swedes, Calder and Crimson King. They have not been seen in Grandmaster though some 15,000 flowers have been examined. Grandmaster was chosen as a normal parent $\left(\mathrm{P}_{2}\right)$, and crosses were made between it and an abnormal Calder plant $\left(\mathrm{P}_{1}\right)$. The pedigrees of these plants are listed in table 8.

One plant each of Calder $(5201 / 1)$, Grandmaster $(5242 / 6)$ and $F_{1}(5244 / 6)$ was used to produce the $F_{1}, F_{2}, P_{1}, P_{2}$ and back-cross generations. The $F_{1}(5244 / 6)$ which had 623 normal and no abnormal flowers, was produced by crossing $3423 / 2 \times$ $34 \mathrm{I} / 4$. In this $F_{1}$ family there were 16 abnormal and 3 normal plants.

In addition to this set of hybrids, $F_{1}$ 's of some crosses between Calder plants and some unrelated normal swedes, N.H 504 and $\mathrm{Y}$, were grown. These $\mathrm{F}_{1}$ 's contained 12 normal plants and 23 abnormals. 


\section{(ii) Results 1955}

There were no differences between reciprocals of the same cross, and they have been lumped in the following tables and discussion.

The frequency distributions of mean expression in the parents and hybrids is shown in fig. $I$.

The $\mathrm{P}_{1}$ distribution appears to be unimodal and continuous, and the $F_{2}$ and $B_{1}$ populations appear to consist of two classes of plants, some producing abnormal flowers, some not, the mean percentage of abnormal flowers being apparently continuously distributed among the affected plants.

It seems reasonable to assume that the ability to produce abnormal flowers is segregating in these populations. The numbers of normal

TABLE 8

Pedigrees of parent plants

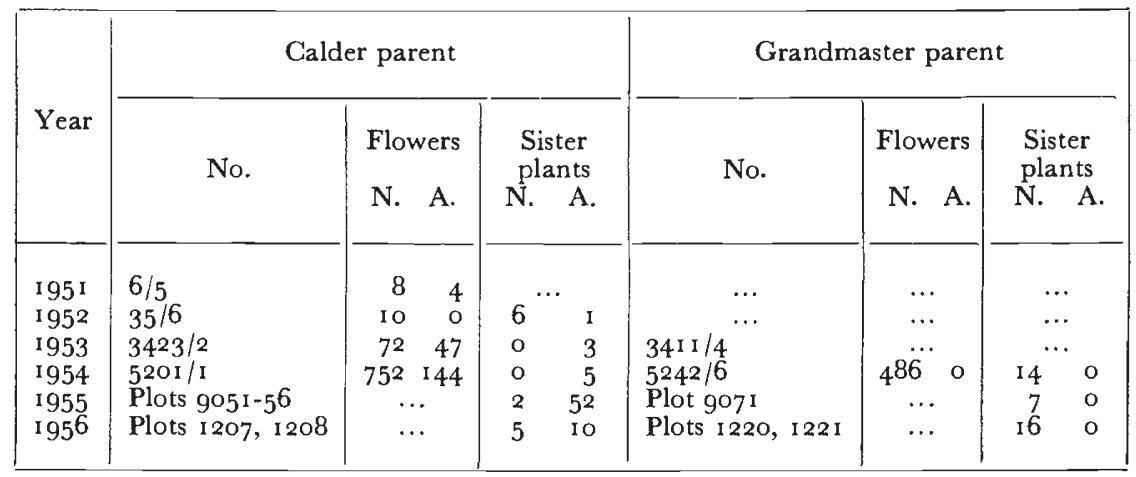

Note-Plots 9051-56 and 1 207, 1208 were derived by successive selfings from plant $6 / 5$ and plots $907 \mathrm{I}$ and $1220,122 \mathrm{I}$ from $34 \mathrm{II} / 4$, also by selfing.

and abnormal plants in the various hybrid and parent populations are given in table 9 .

If the abnormality is caused by one dominant gene with almost complete penetrance in the homozygote, and with penetrance in the heterozygote equal to that in the $\mathrm{F}_{1}$, one would expect the segregation ratios in $\mathrm{BC}_{1}, \mathrm{BC}_{2}$ and $\mathrm{F}_{2}$ to be those shown in columns 4 and 5 of the table. As can be seen, the observed and expected ratios are in close agreement. In addition, if one assumes that the mean expression of affected heterozygotes is that of the $\mathrm{F}_{1}$, one would expect the means of affected plants in the $\mathrm{BC}_{1}, \mathrm{BC}_{2}$ and $\mathrm{F}_{2}$ populations to be those given in the last column of the table. The observed means fall in the expected order.

The hypothesis of a single dominant gene, with penetrance in the homozygote and heterozygote equal to that in $\mathrm{P}_{1}$ and $\mathrm{F}_{1}$, satisfactorily accounts for the observed data.

Some of these plants were progeny tested in 1956 . Data are given in table Io.

The normal $\mathrm{P}_{1}$ (Calder) plant which was tested gave abnormal progeny. So did one of the normal $F_{1}$ plants, and three of the $F_{2}$ 's. 
Normal $P_{1}$ and $F_{1}$ plants gave the same proportion of abnormal progenies as their abnormal sisters. If again the proportion of normals
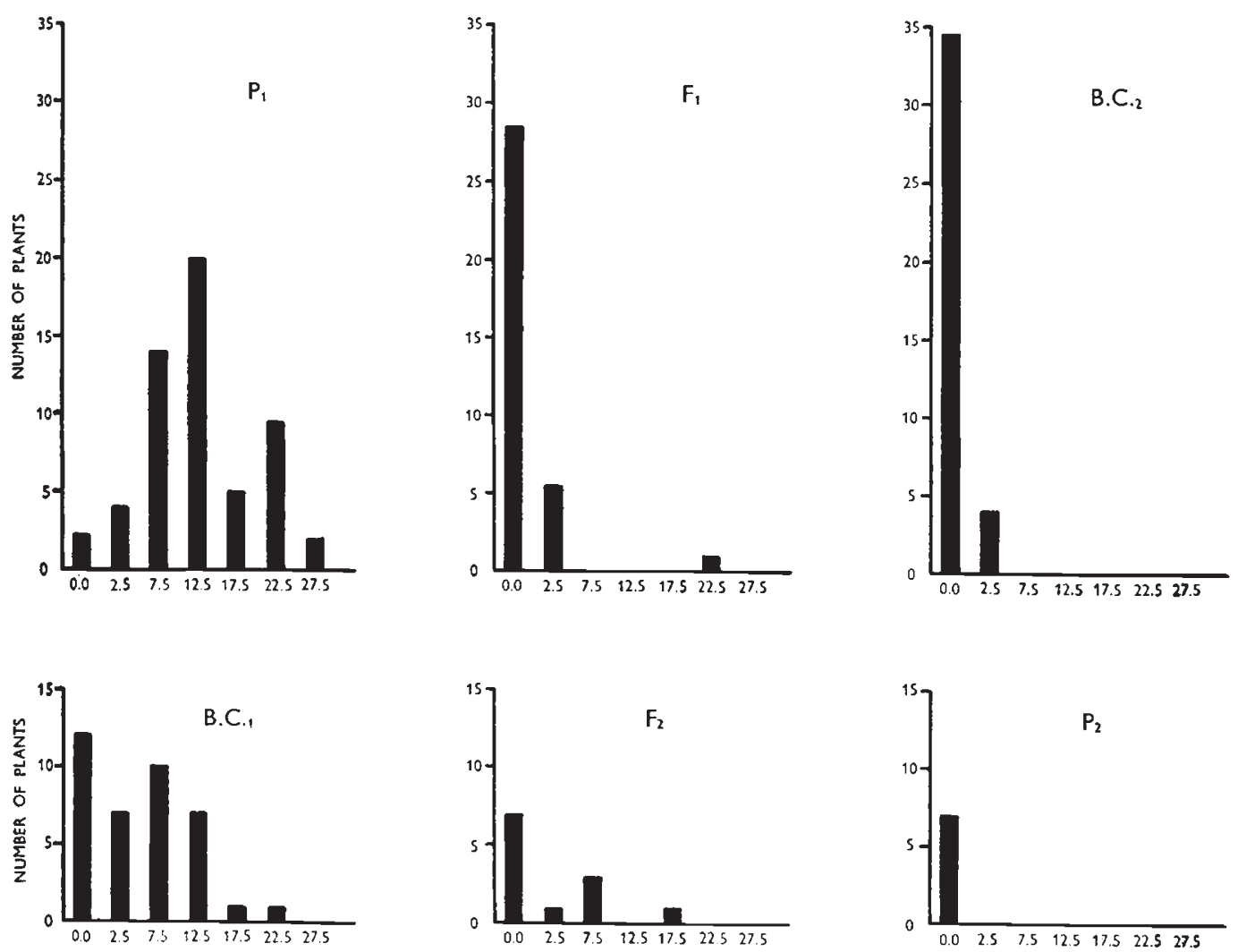

Fig. 1.-Distribution of percentage of abnormal flowers per plant (arc sine transformation) in hybrid swede populations.

TABLE 9

Normal and abnormal plants in swede hybrids, 1955

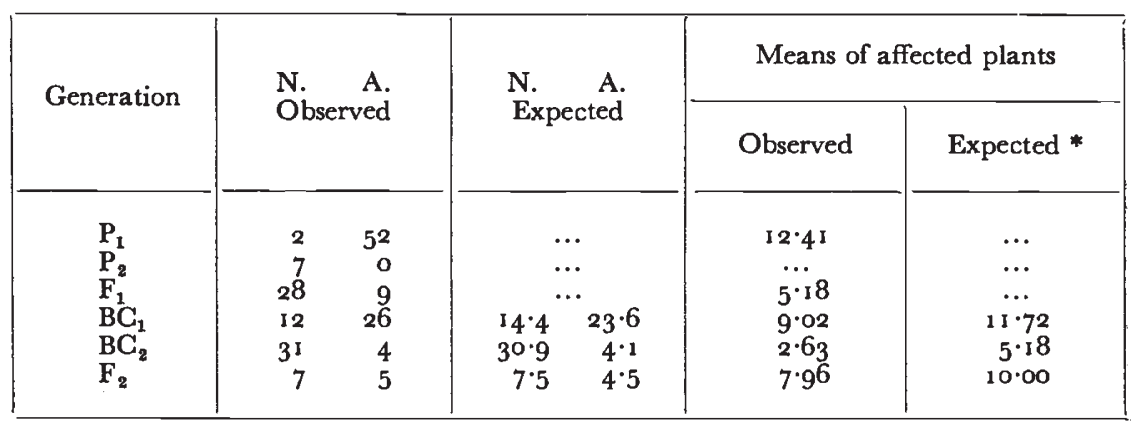

* $\mathrm{BC}_{1}=\left(\mathrm{F}_{1}+{ }_{4} \mathrm{P}_{1}\right) / 5 \quad \mathrm{~F}_{2}=\left(\mathrm{F}_{1}+2 \mathrm{P}_{1}\right) / 3 \quad \mathrm{BC}_{2}=\mathrm{F}_{1}$.

and abnormals in the $P_{1}$ and $F_{1}$ is taken as the penetrance ratio in homozygotes and heterozygotes, one would expect the ratio in $F_{2}$ to be that given in the last column of the table, and an $F_{3}$ produced 
from a random sample of $F_{2}$ plants would segregate in the ratio also given in the last column. As can be seen, there was again a close fit between observed and expected.

TABLE IO

Normal and abnormal plants in swede hybrids, 1956

\begin{tabular}{|c|c|c|c|c|c|c|c|c|c|}
\hline \multirow{3}{*}{$\begin{array}{c}\begin{array}{c}\text { Gener- } \\
\text { ation }\end{array} \\
P_{1}\end{array}$} & \multicolumn{3}{|c|}{ Parent plant } & \multirow{2}{*}{\multicolumn{2}{|c|}{$\begin{array}{c}\text { Progeny } \\
\text { plants }\end{array}$}} & \multicolumn{4}{|c|}{ Generation totals } \\
\hline & No. & Flo & ers & & & Obse & rved & Expe & ted \\
\hline & $\begin{array}{l}9052 / 2 \\
9052 / 6\end{array}$ & $\begin{array}{l}\text { N. } \\
679 \\
797\end{array}$ & $\begin{array}{r}\text { A. } \\
0 \\
53\end{array}$ & $\begin{array}{r}\mathrm{N} . \\
2 \\
3\end{array}$ & $\begin{array}{r}\text { A. } \\
4 \\
6\end{array}$ & $\begin{array}{l}\text { N. } \\
5\end{array}$ & $\begin{array}{l}\text { A. } \\
\text { IO }\end{array}$ & N. & A. \\
\hline $\mathrm{F}_{1}$ & $9051 / 2 \times 9071 / 6$ & $966:$ I 64 & $1085: 0$ & 10 & & 10 & 0 & & \\
\hline$F_{2}$ & $\begin{array}{l}9057 / 1 \\
9057 / 2 \\
9057 / 3 \\
9068 / 2\end{array}$ & $\begin{array}{r}1374 \\
\text { I } 38 \\
810 \\
\text { I } 734\end{array}$ & $\begin{array}{l}0 \\
0 \\
0 \\
1\end{array}$ & $\begin{array}{r}12 \\
8 \\
10 \\
6\end{array}$ & $\begin{array}{l}0 \\
2 \\
0 \\
3\end{array}$ & $3^{6}$ & 5 & $34^{\cdot} \cdot 2$ & $6 \cdot 8$ \\
\hline$F_{3}$ & $\begin{array}{l}9069 / 1 \\
9069 / 2 \\
9069 / 12 \\
9069 / 13 \\
9070 / 2 \\
9070 / 3\end{array}$ & $\begin{array}{r}914 \\
171 \\
530 \\
272 \\
1039 \\
928\end{array}$ & $\begin{array}{r}13 \\
20 \\
0 \\
0 \\
0 \\
0\end{array}$ & $\begin{array}{l}4 \\
8 \\
9 \\
3 \\
8 \\
7\end{array}$ & $\begin{array}{l}5 \\
2 \\
1 \\
0 \\
2 \\
2\end{array}$ & 39 & 12 & $3^{8 \cdot 25}$ & $12 \cdot 75$ \\
\hline $\mathbf{P}_{2}$ & $\begin{array}{l}907 \text { I } / 2 \\
907 \text { I } / 3\end{array}$ & $\begin{array}{l}820 \\
81 \mathrm{C}\end{array}$ & $\begin{array}{l}0 \\
0\end{array}$ & $\begin{array}{r}10 \\
6\end{array}$ & $\begin{array}{l}0 \\
0\end{array}$ & 16 & & & \\
\hline
\end{tabular}

TABLE II

Classification of $F_{3}$ families

\begin{tabular}{|l|cc|c|c|c|}
\hline \multirow{2}{*}{ Plant } & \multicolumn{2}{|c|}{ Progeny } & \multicolumn{3}{|c|}{ Segregation types } \\
\cline { 2 - 5 } & N. A. & I : & $5: 1$ & I $: 2$ \\
\hline & & & & & \\
\hline & & & $*$ & $\ldots$ \\
$9069 / 1$ & 4 & 5 & $*$ & $\ldots$ & $*$ \\
$9069 / 2$ & 8 & 2 & $*$ & $\ldots$ & $\ldots$ \\
$9069 / 12$ & 9 & 1 & $\ldots$ & $\ldots$ & $*$ \\
$9069 / 13$ & 3 & 0 & $\ldots$ & $\ldots$ & $*$ \\
$9070 / 2$ & 8 & 2 & $*$ & $\ldots$ & \\
$9070 / 3$ & 7 & 2 & $*$ & & \\
\hline
\end{tabular}

One would expect the $F_{3}$ families to be of three types, namely all normals, or five normals to one abnormal $\left(=F_{2}\right)$, or I normal to 2 abnormals $\left(=\mathrm{P}_{1}\right)$ these types of families occurring in the familiar I $: 2:$ I ratio. The six $F_{3}$ families are listed in table $I$. 
The asterisks in the cells of the table indicate segregation types to which these families are unlikely to belong. One family (from $9069 / 13$ ) is too small to furnish any evidence. Of the remainder, one could be from a homozygote, and the other four from heterozygotes. The proportions of normal and abnormal plants in these families is not significantly different from $\mathrm{F}_{2}$.

The other notable feature of these data is the lower rate of penetrance in both homozygotes and heterozygotes in 1956 than in I 955 .

In addition to these progeny tests, the $F_{1}, F_{2}, B_{1}$, and $B_{2}$ generations grown in 1955 were grown again in 1956 from seed reserves. Results from this material are set out in table i 2.

TABLE 12

Repeat of 1955 test

\begin{tabular}{|c|c|c|c|}
\hline Generation & Parents & $\begin{array}{r}\text { I955 } \\
\text { N. A. }\end{array}$ & $\begin{array}{l}195^{6} \\
\text { N. A. }\end{array}$ \\
\hline $\begin{array}{l}\mathrm{F}_{1} \\
\mathrm{~F}_{2} \\
\mathrm{BC}_{1} \\
\mathrm{BC}_{2}\end{array}$ & $\begin{array}{l}5242 / 6 \times 5201 / 1 \\
5244 / 6 \mathrm{~S} . \\
5244 / 6 \times 5201 / 1 \\
5244 / 6 \times 5^{242} / 6\end{array}$ & $\begin{aligned} 28 & : 9 \\
7 & : 5 \\
12 & : 26 \\
31 & : 4\end{aligned}$ & $\begin{aligned} \text { I I } & : 3 \\
\text { I } 2 & : 8 \\
0 & : 20 * * \\
\text { I } 6 & : 3\end{aligned}$ \\
\hline
\end{tabular}

Except for the $\mathrm{BC}_{1}$, the tests in the two years are in substantial agreement, and the data from the two years pooled fit the hypothesis. The chances that the two $\mathrm{BC}_{1}$ samples could have come from the same population are somewhere between $\mathrm{I} / 50$ and $\mathrm{I} / \mathrm{I} 00$, and the results from 1956 do not fit the hypothesis. This discrepancy remains unexplained.

Apart from this, these results, with substantial agreement between the same populations grown in both years, suggest that the lower penetrance in the $P_{1}, F_{1}$ and $F_{2}$ populations grown for the first time in 1956 was genetically determined.

\section{(iii) Discussion}

Many cases of incomplete penetrance involve variations in organ numbers, and can be explained by assuming variations in rates of organ formation, or in the time during which susceptible tissues remain in a reactive state (Goldschmidt, I927). In this case, an existing petal divides at some early stage of its development. This may be envisaged as a continuation of the process of differentiation of the petal primordia, which in normal flowers stops when four petals have been laid down, but in abnormal flowers continues long enough for some of the petal primordia to divide again. This lengthening of the period during which petal primordia can differentiate could result from a hastening of differentiation in relation to other processes of 
floral development, or from a lengthening of the period during which differentiation is possible. Either effect could be produced by variations in the amount of evocating substance which initiates differentiation. The correlations between the proportion of flowers and petals affected, and between penetrance and expressivity within families would then be expected.

The variation in the proportion of affected petals from time to time must be attributed to environmental variations, but whether these variations affect the floral embryos directly or through altering the internal environment of the plant is not known. They are apparently not an automatic consequence of the development of the plant, as no consistent pattern of occurrence could be detected. Nor is it surprising that the trait is genetically modified. The process of petal formation in affected plants must be delicately balanced or the abnormality would occur regularly. Variations in penetrance, with their consequent variations in dominance, could result from both genetic and environmental modification.

This character is apparently widespread in the Cruciferae, and the genetic situation underlying its appearance is similar in Brassica napus and Raphanus sativa.

It is not known, however, whether an homologous locus is involved in each species. The present situation might have arisen as a result of mutation followed by the assembling of a system of inhibitors which is occurring in these populations, or it might have arisen from the breakdown of such a system of inhibitors as a result of selection for some other characters. It may be significant that the anomaly has been seen only in cultivated members of the family.

Two main questions remain unanswered. They are the immediate cause of the appearance of the abnormality, which must be some substance produced in the plant or the developing flowers themselves, and the exact nature of the system of genetic modifiers. This material is not particularly suitable for either sort of enquiry. The absence of regularity in the appearance of affected flowers would render the first investigation difficult, while the labour involved in determining the phenotype of plants with a low proportion of abnormal flowers prohibits the use of the larger progenies necessary for a more comprehensive analysis.

\section{SUMMARY}

I. In populations of swede (Brassica napus) curly Kale (B. oleracea), and radish (Raphanus sativa) and evening scented stock (Matthiola bicornis) plants have been seen which bore, on some flowers, divided petals.

2. In the swede and radish the proportion of abnormal flowers varied from time to time on the one plant, though no consistent pattern of occurrence was detected. 
3. The number of petals affected varied more on the radish than swede, and was correlated with the proportion of flowers affected.

4. In the swede and radish populations in which this abnormality was found, lines with varying proportions of abnormal plants, and of varying degrees of abnormality were isolated. The two characters were correlated. No true breeding normal plants were isolated in these populations, but on some plants the proportion of abnormal flowers was as low as $\frac{1}{2000}$.

5. It was concluded that variations in these populations are genetically influenced, some genotypes being more likely to produce abnormal flowers than others. At least two types of families, one producing a higher proportion of abnormal flowers than the other, were shown to occur in these populations.

6. In crosses between these abnormal swedes and plants of a population which is probably without this defect, results could be explained by assuming that one dominant gene with varying penetrance rates in the homozygous and heterozygous condition determined whether or not plants would, or could, produce abnormal flowers.

7. It was suggested that the gene, and its modifiers, act by increasing the production of the substance which initiates petal differentiation.

\section{REFERENCE}

Goldschmidt, R. B. 1927. Physiologische Theorie der Vererbung. Berlin : J. Springer. $247 \mathrm{pp}$. 